\title{
POST-CRISIS MANAGEMENT IN THE HUNGARIAN AUTOMOBILE DEALERSHIP SECTOR
}

\author{
Csaba Bálint Illés \\ Szent Istvan University, Gödöllő, Hungary \\ Beatrix Turzai-Horányi \\ Szent Istvan University, Gödöllő, Hungary \\ Anna Dunay \\ Szent Istvan University, Gödöllő, Hungary
}

\begin{abstract}
Although it is one of the world's most successful industries, the automotive industry was one of the biggest losers of the economic crisis of 2008. The crisis caused negative effects throughout the automobile supply chain, but research about this period has been focused on car dealerships. The objective of this paper is to provide insight gained from comprehensive research conducted in the Hungarian car trade market through in-depth interviews with car dealership owners and a wide questionnaire survey with the managers of car dealerships. The paper focuses on crisis management measures of the post-crisis period. Statistical methods were applied in the analysis of the questionnaire, such as cross-tabulation analysis, chi-squared tests, cluster analysis, variance analysis, and Tukey-type HSD. The study explores the factors and tools for surviving the crisis. Research results confirm that focusing on sales, customer service, and quality are the key factors for keeping and increasing competitiveness and market position..
\end{abstract}

Keywords: automotive industry, car trade market, car dealerships, global economic crisis, crisis management

DOI: http://dx.doi.org/10.15549/jeecar.v8i3.524

\section{INTRODUCTION}

One of the biggest losers of the 2008 crisis was the automotive industry, and the setbacks that occurred in the supply chain were most remarkable at the branded car dealerships. The aim of this research was to explore the impact of the crisis on the development and competitiveness of car dealerships and their recovery from the crisis in different segments in terms of automotive brands.

Due to an artificial increase in demand at the beginning of the 2000s and the car showroom opening program, the number of dealerships and sales reached an unrealistically high level in 
Hungary. The sales network became oversized 3-4 times bigger than necessary - and its structure was inefficient. In 2002, 1100 showrooms existed with 30-35 thousand employees. Sales increased by almost $15 \%$ between 2002 and 2009. The high number of dealerships led to increasing competition, and dealerships had to comply with serious development requirements. According to the newsletter of the Hungarian Association of Automobile Dealers (www.gemosz.hu), after the crisis, in 2011, there were only 420 dealerships, with the number of employees dropping by $60 \%$.

The main research objective was to provide a situation analysis of the Hungarian automotive industry based on secondary and primary data and focusing on trade. With the help of different methods, the numbers of car dealerships, showrooms, sites, owners, and registered new cars were analyzed and evaluated before, during and after the 2008 global financial crisis.

The research aimed to assess dealers' strategies, unfold how the crisis impacted them, and the most critical factors in their success that helped them in their survival.

\section{LITERATURE REVIEW AND RESEARCH BACKGROUND}

In the automotive industry in the decade before the crisis of 2008, mass production and continuous expansion were common, which brought market saturation and over supply (Humphrey and Memedovic, 2003). In Western Europe, overproduction reached $22 \%$, i.e. 5 million cars/year (Becker, 2006). The fragmented market made sales prediction difficult, and manufacturers (Original Equipment Manufacturers - OEMs) and suppliers had to make their decisions based on volumes. This situation made the market vulnerable (Orsato and Wells, 2007).

The structure of the automotive industry changed due to this situation, and the importance of upstream and downstream activities changed as well (Nieuwenhuis and Wells, 2004). In the structure of the automotive value system, upstream activities are played by different levels (Tier 1, 2 and 3), while downstream activities cover automotive divisions (production and sales of cars and parts) and different financial services such as financing, fleet management and mobility services (Lung, 2004). In the past decade. The main changes in the upstream system have been characterized by a reinforced competencies transfer trend, the continuation of suppliers' concentration, diversification in activities and a significantly more complex system (Becker, 2006).

In the original model of the automotive supply chain, production, assembly and the sale of cars and spare parts played the primary role in value creation, but in present times other, secondary sources are also needed for completing a successful life cycle of a car (Wells, 2010).

Downstream activities are connected to the sale and use phase of a car. The original actors of downstream activities were dealers, fleet management companies and other service suppliers. Later, in the 2000s, new roles have been added to these activities, such as car finance, leasing, insurance, accessories and replacement parts (Nieuwenhuis and Wells, 2004).

Nowadays, an increasing level of competition can be observed in the automotive supply chain that is defined by the need for different personalized solutions. Players in the sector need to monitor consumer expectations in order to maintain their efficiency, and they need to pay special attention to handle problems of uncertainty in their strategies (Kopeček and Pinte, 2014). The automotive sector has a special supply chain in which vehicles start at the factory reach the final customer at the car dealerships through distribution centers. The different aspects of the automotive industry supply chain have been analyzed by many researchers in the past two decades (Sánchez and Pérez, 2005; Mészáros, 2010; Thun and Hoenig, 2011; Szegedi et al., 2017).

Stros et al. (2019) and Miskolcziné Gábriel (2017) each discussed the upstream side of the automotive industry supply chain, with the former focused on sales and the latter on green supply chain management. Dömötörfi and Péter (2016), based on the results of Zhang (2014), elaborated on an expanded network model, indicating the multiple relations between suppliers.

Through the mid-1990s, the manufacturers Suzuki, Opel and Audi in Hungary created large 
trading and importing companies in Hungary (Humphrey and Memedovic, 2003). These forms of investment were common in Central Eastern European countries at that time (Radosevic and Rozeik, 2005; Jakubiak et al., 2008; Pavlínek and Zenka, 2011).

The world economic crisis of 2008 accelerated the structural transformation of the automotive sector. Production and trade were organized at a mainly regional level instead of the global level. Additionally, as covered by the research of Balcet and Ruet (2011) and Balcet et al., (2012), new actors appeared in the market of the global automotive industry, namely developing country multinational companies. Moreover, the transformation of the business model was expected in the future due to the increasing competence and market power of suppliers. The crisis negatively affected the passenger car sector. Markets became saturated, as a surplus in capacity could be seen as people purchased cars using bank loans and an increasing demand appeared regarding more energy-saving cars (Antalóczy and Sass, 2011). The original market of 240,000 cars dropped to 45,000 thousand cars in 2009 and 2010 (Gablini interview, 2017). Nevertheless, the crisis affected and destroyed not only the Hungarian car market, but stakeholders in neighboring countries have experienced the same problems as well (Winter, 2010; Van Biesebroeck and Sturgeon, 2010; Fortwengel, 2011).

Although the research focused on new car sales, it is also important to mention the market of used cars since it has had a high level of importance in Hungary and has impacted the market for new vehicles. Before the outbreak of the crisis in 2007 and 2008, the average age of cars decreased to around 10 years, and more than 150,000 new and only 20,000 used cars were registered. In 2009, however, new car registrations dropped to 63,000 and used car registrations started to increase. In 2016, used car registration was higher than new by $37 \%$ (Datahouse Kft database).

Due to these warning signs, the governments of many countries started to take different measures in order to promote purchasing and to maintain competitiveness in different sectors (Matysek-Jędrych, 2014). One of these measures in the automotive industry was the so-called vehicle replacement scheme that provided financial support for those customers who wanted to change their old, polluting, and energy inefficient cars for a new one (OECD, 2010).

Based on the above, the research questions to be answered by this study are:

- What kind of operation changes were the result of the 2008 crisis?

- What difficulties must car trade markets face?

- Which car trade markets can stay competitive for the long term?

\section{DATA AND METHODOLOGY OF THE RESEARCH}

Secondary databases, obtained from the Hungarian Association of Automobile Dealers and Datahouse Kft, were used for the assessment of the domestic market. As a next step, in-depth interviews and questionnaires were conducted to explore the effects of the 2008 crisis on the Hungarian car dealerships with the highest possible accuracy. Structured in-depth interviews were done with the leaders of dealerships to explore the impacts of the crisis and to get detailed information about their opinion, experiences and future visions.

A wide questionnaire survey was also conducted that focused on the dealers' strategies, the business models they applied, the factors influencing competitiveness, the role of importers, and the effects of the crisis. In the first half of the questionnaire, after demographic data, including the location of the dealership was gathered, the number of sites and brands and the details of ownership was asked to unfold the corresponding advantages, disadvantages and problems. The second part of the questionnaire was about the competitiveness and strategies of the dealerships (e.g. facts about management and employee training, tools for the recovery from the crisis, the maintenance of customer relationships, communication, the role of the internet, and the development of the cost structure), and the impact of the crisis.

In Hungary, 405 dealerships were in operation in 2015 by 249 owners. Following inquiries through the phone, personally or via email, indepth interviews were carried out with 21 owners/managers, out of which 18 owners have 
only one site where they distribute only one brand. In the second phase of the research, the questionnaire was sent by the Association to all the 405 dealerships; 60 questionnaires were sent back for a $15 \%$ response rate.

Relying on the literature and the preliminary research findings, the dealerships were classified into 4 groups based on the number of brands they are dealing with and the number of sites where they are operating: one brand/one site, one brand/multiple sites, multiple brands/one site, and multiple brands/multiple sites.

Different statistical methods were applied to the questionnaire analysis. Among others, crosstabulation analysis and chi-squared tests were examined whether the relationship is verifiable. Cluster analysis was conducted to show how the examined dealerships might be grouped in terms of their strategies and the method of variance analysis was used for the examination of the competitiveness of the dealerships. Among these methods, the Wilcoxon test, correlation calculations and variance analysis were conducted for the examination of the impacts of the crisis, the unfolding of the details of crisis management, and establishing the details of the competitiveness of the players.

\section{RESEARCH RESULTS AND DISCUSSION}

During the in-depth interviews, owners confirmed that, because of the crisis of 2008 , the car market collapsed, and dealerships faced the biggest crisis ever in their lives, all of external origin. Besides reducing and restructuring costs, the reduction of the number of employees could also be observed in the analyzed companies, and most of them started to focus more on customer service to survive the dramatic decline of sales. Additionally, owners tried to survive the crisis by focusing on better financial management and improving their customer services (Table 3 ). Many of the analyzed dealerships operated previously two sites, but due to the crisis they were forced to close down one of them. Many of the dealerships turned to general car service activities by starting service for more brands in order to survive. Some dealerships started reexporting activities, which meant that the new car was registered in Hungary, provided with a registration plate and immediately withdrawn from the market. Afterwards, it was taken abroad to another dealership and sold there. Finally, most of the dealership leaders mentioned more conscious financial management.

In many cases, development and enlargement and training of employees also appeared, mainly at those dealerships which represented more brands and/or operated at more sites. In the case of financial investors, where they owned other companies as well and were stronger in terms of capital, losses stemmed from the crisis could be borne more easily; moreover this was thought to be the means of differentiating themselves from others. More of them started enlarging showrooms and/or car services or tried to extend the circle of services they provided. Those companies in which development or enlargement was commenced represented higher price category cars. The managers of such dealerships added that even though their sales dropped, their clients were not primarily affected by the crisis, as they did not sell so many cars with a starting amount of 0 HUF, so the decrease was not so dramatic in their case.

After 2008, companies representing more brands and/or operating more sites felt the decline of sales and some had to reduce the number of employees or close sites. However, it can be seen that compared to other dealerships (one brand/one site), the purchaser ratio is better. They managed to stay profitable throughout the crisis in more cases, and there were companies that opened new showrooms and sites.

Unfortunately, the crisis lasted longer than owners and automotive industry experts thought. They expected it would last 2-3 years, after which sales would rise again, but, instead they had to wait 5-6 years until they could again look ahead positively.

The results of in-depth interviews showed that the owners and managers of dealerships consider workforce-related factors as the riskiest, i.e. workforce scarcity, lack of vocational training and the increase in labor costs. $60-70 \%$ of the responding owners and/or managers considered these factors to be the most significant sources of risk. These factors were followed by the influence from the importers, which was also mentioned at the in-depth interviews by everyone, regardless of the brand, site, owner or manager (Figure 1). However, 
managers of the companies have recently faced new challenges, namely the lack of appropriate junior and skilled workforce with professional experience; this was mentioned in all in-depth interviews and were confirmed by the results of the questionnaire.

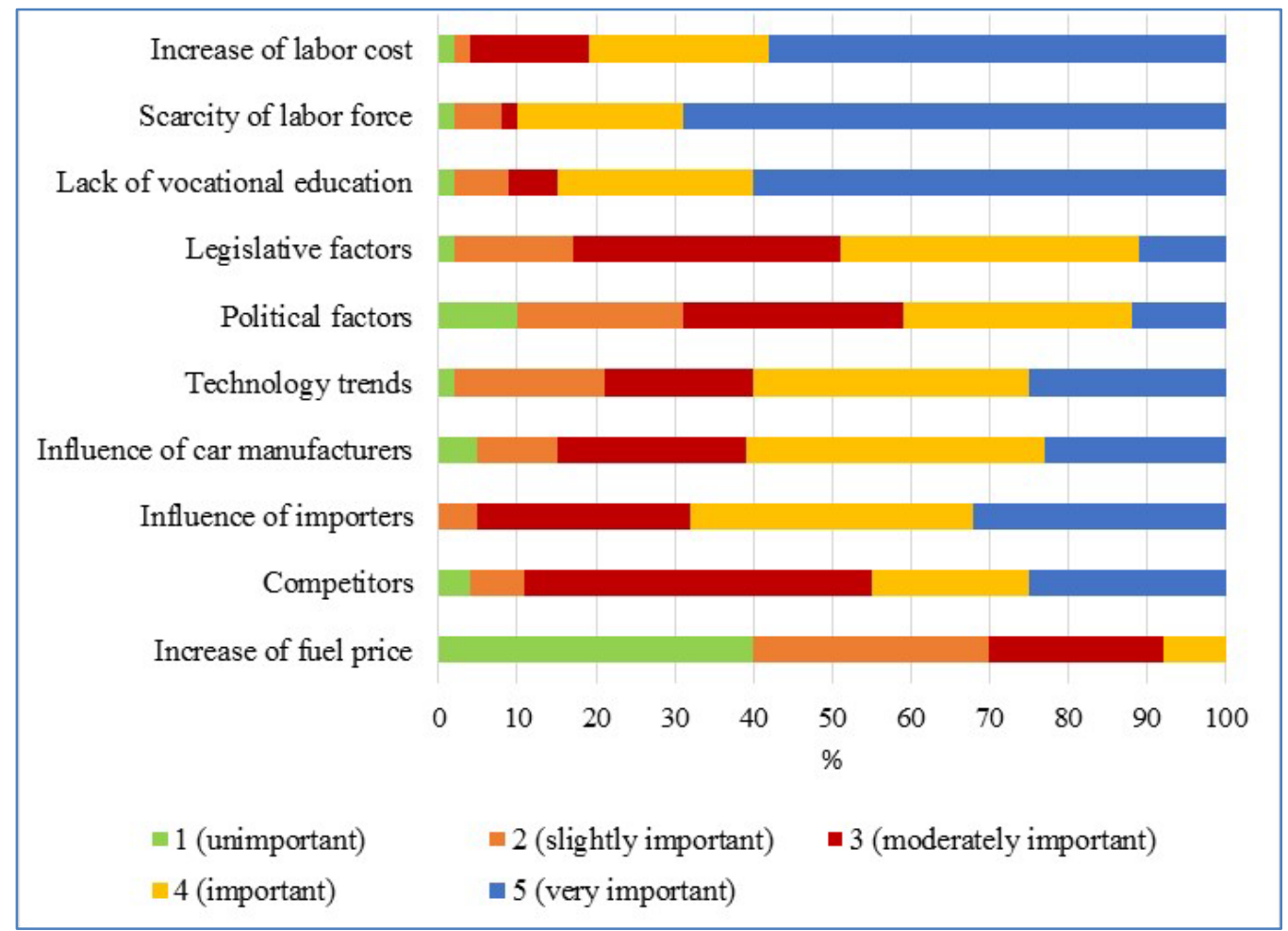

Figure 1: Ratios of the relevance of risk factors in the sector

Source: own analysis (Turzai-Horányi, 2019)

Which risk factors were considered by the dealerships when preparing their strategies was scrutinized. In accordance with the findings from the previous question related to risk factors, dealers should consider the insufficient vocational training and limited availability of the workforce in their planning. The answers to this question are summarized in Table 1.

Table 1: Risk factors considered by the dealerships at their strategic planning

\begin{tabular}{|l|c|}
\hline \multicolumn{1}{|c|}{ Risk factors } & $\%$ \\
\hline No risks considered & 1.67 \\
\hline Limited availability of workforce & 65.00 \\
\hline Insufficient vocational training & 53.33 \\
\hline Legal & 20.00 \\
\hline Political & 15.00 \\
\hline Market (competitors, importers, manufacturers) & 85.00 \\
\hline Financial & 90.00 \\
\hline
\end{tabular}

Source: own analysis

It is noted that the managers primarily consider the financial and market risks (90\% and 85\%) when making strategic decisions. They focus on sales and development opportunities in their annual business plans, tasks which are mostly impacted by financial and market 
(competitors, importers, manufacturers) conditions. A limited amount of skilled workers represents also an important issue (65\%), which has roots in insufficient vocational training (53,33\%). This may raise a long-lasting problem for dealerships, which offer service and maintenance for the cars sold, and, of course, it is not a manager-related decision, but an external influencing factor.

As an answer for the question about how they could manage and resolve the lack of expertise and vocational education, owners mentioned higher wages and training.

Following the outbreak of the crisis in 2008, dealerships had three ways to follow. Significant parts of the companies were closed, as can be seen mostly in case of the Suzuki showrooms. Half of the surviving dealerships intended to involve external resources to survive by bank loans and $46 \%$ tried to manage the situation with internal resources. The least frequent solution was to share capital by inviting new equity partners; only two owners applied this financing method.

In the past 10 years, surviving dealerships have had to apply various changes at more areas. The research also analyzed which areas dealerships were forced to change and which concrete steps they could realize from these. As is displayed in Table 2, all of the respondents decreased or restructured their expenses, more than $2 / 3^{\text {rds }}$ of them changed their marketing, more than half of them reshaped their scope of activities, and the same quantity undertook dismissal of employees.

Table 2: Ratio of crisis management measures realized on different fields following to the crisis

\begin{tabular}{|l|c|}
\hline \multicolumn{1}{|c|}{ Measures } & $\%$ \\
\hline Dismissal of employees & $55.17 \%$ \\
\hline Decreasing and restructuring expenses & $100.00 \%$ \\
\hline Changes in marketing & $67.24 \%$ \\
\hline Modifying payment constructions & $41.38 \%$ \\
\hline Broadening and reshaping the scope of activities & $55.17 \%$ \\
\hline
\end{tabular}

Source: own analysis

After the outbreak of the 2008 crisis, the number of showrooms dropped by almost $40 \%$. As a result, the characteristics and activities that helped companies survive this period and maintain their activities were examined. The results are indicated in Table 3. Approximately
$90 \%$ of the respondents marked good financial management as a main tool that helped them survive the crisis, but $75 \%$ of them also considered good customer service as very important.

Table 3: Characteristics and activities that helped survival of the crisis

\begin{tabular}{|l|c|}
\hline \multicolumn{1}{|c|}{ Activities } & $\%$ \\
\hline Involving new owner & $6.78 \%$ \\
\hline Re-export & $18.64 \%$ \\
\hline Good financial management & $89.83 \%$ \\
\hline Good customer service & $74.58 \%$ \\
\hline
\end{tabular}

Source: own analysis

The reasons and characteristics that led to the closure of certain dealerships were also examined in the research. As the owners of these dealerships were unwilling to respond, only the opinion of the still operating dealerships was available, which provided indirect information on the shortcomings of companies that were not able to survive.

Owners/managers of the dealerships were asked what could have been be the main reasons 
for the termination of the dealerships that could not survive the crisis in the questionnaire, specifically: are the reasons sector-specific (i.e. related to all dealerships), brand-specific or related to personal problems. Results show similar characteristics in both cases; inappropriate management and the spending of dividends was mentioned frequently. Almost $50 \%$ of the respondents indicated that inconvenient customer service and young age of the dealership were also among the main reasons that some enterprises could not survive the crisis.

Due to the showroom opening program in Hungary, dealerships were opened at the beginning of the 2000s, however they did not have proper professional or financial background. Dealerships mostly focused on sales, hence after the outbreak of the crisis they had not enough strength, experience, customers, and clientele which could help them survive.

Answers by all respondents regarding the strength and direction of correlation of the two variables were analyzed. The respondents were asked about these negative characteristics in general and in relation to similar dealerships. The correlation was checked using cross-table analysis and the gamma index, and it was found that the relation is very strong between these factors. In almost all cases, when the respondent qualified one of the factors as negative at similar dealerships, they marked the same factor in general as a main problem.

The examination of the changes in the automotive dealership sector justified the analysis of the competitiveness of dealerships, particularly how they saw their own situation and how they compared their own competitiveness to their peers. To address this, owners/managers were asked two questions about how they positioned and ranked themselves in comparison to their competitors. In the first question, they were asked to place their dealership in relation to their strongest competitor on a scale between 1 to 5 with respect to the following:

- Technology used during service and repair;

- Techniques and technologies used during sales;

- General competitiveness of the dealership;

- Quality of customer service;

- Meeting customers' requirements.

The next question for the evaluation of competitiveness in relation to competitors addressed profitability, growth and stability.

During the analysis and assessment of results, four groups were used that were earlier defined and applied. Results of the descriptive statistics are displayed in Table 4.

Table 4: Results of examination of competitiveness of groups set up from the examined dealerships

\begin{tabular}{|c|c|c|c|c|c|c|c|}
\hline \multirow{2}{*}{\multicolumn{2}{|c|}{ Type }} & \multicolumn{2}{|c|}{ Number of cases } & \multirow{2}{*}{ Average } & \multirow{2}{*}{ Median } & \multirow{2}{*}{ Modus } & \multirow{2}{*}{ Dispersion } \\
\hline & & Valid & Missing & & & & \\
\hline \multirow{4}{*}{$\begin{array}{l}\text { Competitiveness } \\
\text { compared to the } \\
\text { strongest } \\
\text { competitor (1-5) }\end{array}$} & 1S 1B & 16 & 0 & 3.8 & 4.0 & 4.0 & 0.57 \\
\hline & $1 \mathrm{~S} \mathrm{mB}$ & 10 & 0 & 4.8 & 5.0 & 5.0 & 0.23 \\
\hline & $\mathrm{mS} 1 \mathrm{~B}$ & 11 & 0 & 4.2 & 4.4 & 5.0 & 0.66 \\
\hline & $\mathrm{mS} \mathrm{mB}$ & 23 & 0 & 4.2 & 4.4 & 4.5 & 0.56 \\
\hline \multirow{4}{*}{$\begin{array}{l}\text { Current } \\
\text { competitiveness } \\
\text { of the dealership } \\
(1-5)\end{array}$} & 1S 1B & 16 & 0 & 3.4 & 3.5 & 4.0 & 0.87 \\
\hline & $1 \mathrm{~S} \mathrm{mB}$ & 10 & 0 & 4.6 & 4.9 & 5.0 & 0.50 \\
\hline & $\mathrm{mS} 1 \mathrm{~B}$ & 11 & 0 & 4.0 & 4.0 & 4.0 & 0.72 \\
\hline & $\mathrm{mS} \mathrm{mB}$ & 23 & 0 & 3.9 & 4.0 & 4.0 & 0.77 \\
\hline \multirow{4}{*}{$\begin{array}{l}\text { Competitiveness } \\
(1-5) \text { measured } \\
\text { based on } \\
\text { questions } 27-28\end{array}$} & 1S 1B & 16 & 0 & 3.7 & 3.6 & 3.4 & 0.42 \\
\hline & $1 \mathrm{~S} \mathrm{mB}$ & 10 & 0 & 4.7 & 4.8 & 5.0 & 0.27 \\
\hline & $\mathrm{mS} 1 \mathrm{~B}$ & 11 & 0 & 4.2 & 4.1 & 4.1 & 0.53 \\
\hline & $\mathrm{mS} \mathrm{mB}$ & 23 & 0 & 4.1 & 4.1 & 4.5 & 0.50 \\
\hline
\end{tabular}

Legend: 1S 1B: 1 site/1 brand; $1 \mathrm{~S} \mathrm{mB:} 1$ site/multiple brands; $\mathrm{mS} 1 \mathrm{~B}$ multiple sites/1 brand; $\mathrm{mS} \mathrm{mB}$ : multiple sites/multiple brands

Source: own analysis (Turzai-Horányi, 2019) 
Table 4 shows that in all three cases in which competitiveness was compared to the strongest competitor one site/multiple brand dealerships are the most competitive.
Variance analysis was conducted to see if significant deviation can be justified between these averages, with the results summarized in Table 5.

Table 5: Result of variance analysis

\begin{tabular}{|c|c|c|c|c|c|c|}
\hline \multicolumn{7}{|c|}{ ANOVA } \\
\hline & & $\begin{array}{l}\text { Sq. } \\
\text { dev. }\end{array}$ & $\begin{array}{l}\text { D. of } \\
\text { fr. }\end{array}$ & $\begin{array}{r}\text { St. } \\
\text { dev. }\end{array}$ & $\mathrm{F}$ & Sig. \\
\hline \multirow{3}{*}{$\begin{array}{l}\text { Competitiveness } \\
\text { compared to the } \\
\text { strongest } \\
\text { competitor }(1-5)\end{array}$} & Between groups & 5.872 & 3 & 1.957 & 6.644 & 0.001 \\
\hline & Within group & 16.496 & 56 & 0.295 & & \\
\hline & In total & 22.367 & 59 & & & \\
\hline \multirow{3}{*}{$\begin{array}{l}\text { Current } \\
\text { competitiveness of } \\
\text { the dealership ( } 1 \text { - } \\
5 \text { ) }\end{array}$} & Between groups & 8.802 & 3 & 2.934 & 5.206 & 0.003 \\
\hline & Within group & 31.560 & 56 & 0.564 & & \\
\hline & In total & 40.362 & 59 & & & \\
\hline \multirow{3}{*}{$\begin{array}{l}\text { Competitiveness } \\
\text { (1-5) measured by } \\
\text { questions } 27-28\end{array}$} & Between groups & 6.829 & 3 & 2.276 & $\begin{array}{r}10.93 \\
3\end{array}$ & 0.000 \\
\hline & Within group & 11.660 & 56 & 0.208 & & \\
\hline & In total & 18.489 & 59 & & & \\
\hline
\end{tabular}

Legend: Sq. dev. = Squared deviation, D. of fr. = Degree of Freedom, St. dev.= Standard deviation, Sign.= Significance

Source: own analysis (Turzai-Horányi, 2019)

Based on the strongly significant $(p<0,01)$ result of the variance analysis, the significant deviation can be justified between the group averages in all three cases. In the case of the significant result of the F-test, in order to define groups showing significant deviation, the Tukeytype HSD real significant difference posthoc test was also used (Table 6.). The result of the posthoc test supports that in the case of competitiveness compared to the strongest competitor, the current competitiveness of the dealership and competitiveness measured collectively, one site/multibrand dealerships are the most competitive.

During the in-depth interviews, managers of the dealerships highlighted more benefits of sales activities at multiple sites. At the same time, the result of the questionnaire survey shows that benefits due to multi-site activities are not sufficient for the owners to expand and develop their activities in such a direction.

It seems that a rational and achievable goal for them is increasing the efficiency and competitiveness of the dealerships. Increasing efficiency requires improvement in hard (technology-based) and soft (human resourcebased) factors, as was similarly highlighted by Fortwengel (2011) and Matysek-Jędrych (2014). In addition to finding proper expert workers, the increase of the number of employees is also an important step for further development. Many dealership owners intend to open further sites or involve other brands as a special solution for keeping their position and to be able to grow. A similar situation is seen in Slovakia (Pavlínek and Zenka, 2011) and in other developing, non-EU countries (Van Biesebroeck and Sturgeon, 2010; Sturgeon and Van Biesebroeck, 2011). 
Table 6: Result of Tukey-type HSD post-hoc test

\begin{tabular}{|c|c|c|c|c|}
\hline \multicolumn{4}{|c|}{$\begin{array}{l}\text { Competitiveness compared to the strongest } \\
\text { competitor }\end{array}$} & \\
\hline \multirow{2}{*}{ Type } & \multirow{2}{*}{$\begin{array}{l}\text { Number } \\
\text { of cases }\end{array}$} & \multirow{2}{*}{\multicolumn{2}{|c|}{2}} & \\
\hline & & & & \\
\hline 1S 1B & 16 & 3.8 & & \\
\hline $\mathrm{mS} \mathrm{mB}$ & 23 & 4.2 & & \\
\hline $\mathrm{mS}$ 1B & 11 & 4.2 & & \\
\hline $1 \mathrm{~S} \mathrm{mB}$ & 10 & & 4.8 & \\
\hline Sig. & & 0.231 & 1.000 & \\
\hline \multicolumn{4}{|c|}{ Current competitiveness of the dealership } & \\
\hline \multirow{2}{*}{ Type } & \multirow{2}{*}{$\begin{array}{l}\text { Number } \\
\text { of cases }\end{array}$} & & & \\
\hline & & 1 & 2 & \\
\hline 1S 1B & 16 & 3.4 & & \\
\hline $\mathrm{mS} \mathrm{mB}$ & 23 & 3.9 & 3.9 & \\
\hline $\mathrm{mS}$ 1B & 11 & 4.0 & 4.0 & \\
\hline $1 \mathrm{~S} \mathrm{mB}$ & 10 & & 4.6 & \\
\hline Sig. & & 0.130 & 0.129 & \\
\hline \multicolumn{5}{|c|}{ Competitiveness measured collectively } \\
\hline \multirow{2}{*}{ Type } & \multirow{2}{*}{$\begin{array}{l}\text { Number } \\
\text { of cases }\end{array}$} & & & \\
\hline & & 1 & 2 & 3 \\
\hline 1S 1B & 16 & 3.7 & & \\
\hline $\mathrm{mS} \mathrm{mB}$ & 23 & 4.1 & 4.1 & \\
\hline $\mathrm{mS} 1 \mathrm{~B}$ & 11 & & 4.2 & \\
\hline $1 \mathrm{~S} \mathrm{mB}$ & 10 & & & 4.7 \\
\hline Sig. & & 0.074 & 0.989 & 1.000 \\
\hline
\end{tabular}

Source: own analysis

The recent COVID-19 crisis raised new challenges for the automotive sector. Hoeft (2021) highlighted the fundamental principles of crisis management for the players in the automotive supply chain, namely having a clear direction of where to take the company, having definite key performance indicators for all employees, collaborating with key partners, and finally, ensuring continuous learning about improving the agile strategy process (Hoeft, 2021). These recommendations may be applied for Hungarian dealerships as well.

An additional significant challenge for the future management of companies is the question of succession, which is an important problem, as owners of the examined dealerships will reach retirement age very soon, and, therefore, they put more focus on this question. The car dealerships operate mainly as a family business - especially the one-brand/one-site dealerships hence founders set as a primary goal passing it on to family members. Problems could arise, however, if the children are not interested in continuing the family business. This question is to be discussed as the next stage of the research.

Establishing close relationships with clients also plays an important role for dealerships, and they should try to follow new methods and adapt to new trends of mobility as much as possible. Digital experience, location of the dealership, internet availability and the post-purchasing experience represent more and more influential 
factors in the competitiveness of dealerships. According to a survey, internet use by clients was only $15 \%$ in 2000 but reached nearly $90 \%$ by 2016 (Mohr, 2013; Deloitte.com, 2017).

\section{CONCLUSIONS AND RECOMMENDATIONS}

The results of the research confirmed the assumption that focusing only on sales is not sufficient for surviving in the long term and for maintaining competitiveness. Those dealerships that put customer service in the background either did not survive the 2008 crisis or they survived but only by paying a very high price. Due to restructuring, reengineering and austerity measures within the company, as well as the result of increasing demand and willingness to pay, car dealerships have begun to develop over the past few years. Nevertheless, the permanent changes of the external environment (in political, economic, social, technological and environmental issues) should be taken into consideration in the formulation of effective strategies. In addition, future trends influencing power should not be underestimated, as these factors will influence the existence, development and competitiveness of all players in the automobile sector, including car dealerships.

It should be of Interest to dealerships and importers (or manufacturers) that importers rather supported dealerships with one brand and one site rather than multi brands in recent years.

The results of the research show that a higher ratio of one brand dealerships was observed until 2008 for brands such as Nissan, Seat or Honda (but not Suzuki). In the case of dealierships which did not survive the global economic crisis and went bankrupt, the reason could be that purchasing power dramatically decreased, the showrooms of the mentioned dealerships became empty, and dealerships that were relatively close to each other within one city could not survive.

Because manufacturers also cooperate more intensely, however, a special situation can be observed between the players in that maybe only a universal workshop will be required for service and repair. In spite of all this, dealerships want to keep the customers for themselves and serve them in every area of customer service.

In addition, to increase consumer satisfaction, clients should be served at the highest level; car dealerships should consider expanding their distribution to more brands.

The research results are in many respects exploratory and can be a guideline for the dealerships and can be the basis of further research. The main goals for the future are extending the research beyond country borders and investigating all the key participants of the supply chain who strongly influence dealership competitiveness.

\section{REFERENCES}

Antalóczy, K., Sass, M. 2011. Válságkezelés előremeneküléssel. Külgazdaság LV. 31-63

Balcet, G., Ruet, J. 2011. From joint ventures to national champions or global players? Alliances and technological catching-up in Chinese and Indian automotive industries, ERIEP European Review of Industrial Economics and Policy, December, No. 3, 1-24

Balcet, G., Wang, H. and Richet, X. 2012. Geely A Trajectory of Catching Up and Assetseeking Multinational Growth, International Journal of Automotive Management, 4 (12) 360-375. https://doi.org/10.1504/IJATM.2012.051361

Becker, H. 2006. High Noon in the Automotive Industry. Institute for Economic Analysis and Communication, Springer-Verlag, Berlin Heidelberg.

DATAHOUSE Kft database (2006-2017) (nonpublic reports and documents)

Deloitte.com 2017. Automotive customer service becomes a relationship-based consumer experience. Dealers should prepare now for a new mobility. https://www2.deloitte.com/us/en/pages/ma nufacturing/articles/relationshipbasedautomotive-consumer-experienceand-customer-service.html

Dömötörfi, Á., Péter, T. 2016. Autóipari ellátási láncok modern modellezésének lehetőségei. IFFK Konferenciasorozat, Budapest, 159-164

Fleischer, T. 2011. Közlekedés és fenntarthatóság - különös tekintettel az EU 2011-es közlekedési fehér könyvére Európai Tükör 16(5) 23-38. 
Fortwengel, J. 2011. Upgrading through Integration? The Case of the Central Eastern European Automotive Industry. Transcience Journal, 2(1) 1-25.

Gablini interview, 2017. In depth interview with Mr. Gabor Gablini president of GÉMOSZ

Hoeft, F. 2021. The case of sales in the automotive industry during the COVID-19 pandemic, Strategic Change, 30(2), https://doi.org/10.1002/jsc.2395

Humphrey, J. Memedovic, O. 2003. The Global Automotive Industry Value Chain: What Prospects for Upgrading by Developing Countries. UNIDO Sectorial Studies Series Working Paper. http://dx.doi.org/10.2139/ssrn.424560

Jakubiak M. Kolesar P. Izvorski I. Kurekova L. 2008. The Automotive Industry in the Slovak Republik: Recent Developments and Impact on Growth. Commission on Growth and Development. Working Paper No.29. The World Bank Group, Washington DC.

Kopeček, P., Pinte, M. 2014. Optimization Heuristics for Supplies of Assembly Lines. Periodica Polytechnica Transportation Engineering. 42(1), 49-51. https://doi.org/10.3311/PPtr.7118

Lung, Y. 2004. The Challenges of the European Automotive Industry at the beginning of the 21st century. Cahier du GRES. E3i, IFReDEGRES et GERPISA

Matysek-Jędrych, A. (2014). The Role of Government in Restoring International Competitiveness: the Case of Crisis Management in the Baltic States Economies versus Poland Economies. Journal of Eastern European and Central Asian Research 1(1), 11. https://doi.org/10.15549/jeecar.v1i1.35

Mészáros, Á. 2010. A válság utáni autóipari beszállítói rendszerek és a hazai beszállítók lehetőségei. Vezetéstudomány 10, 19-26

Miskolcziné Gábriel, M. 2017. Zöld ellátási lánc menedzsment átfogó vizsgálata a hazai közúti gépjármúiparban - Doctoral Thesis, Szent István University, Gödöllő, Hungary

Mohr, D. 2013. The road to 2020 and beyond: What's driving the global automotive industry? McKinsey\&Company. Stuttgart. Report, 28. p.
Nieuwenhuis, P. Wells, P. 2004. The automotive industry and the environment. Centre for Automotive Industry Research (CAIR) at Cardiff University, Woodhead Publishing in Environmental Management. Abington Hall, Abington.

OECD 2010. Chapter 2. The Automobile industry in and beyond the crisis, http://www.oecd.org/eco/outlook/44089863 .pdf (Access: 18 January 2014.)

Orsato, R. Wells, P. 2007. U-turn: the rise and demise of the automobile industry. Journal of Cleaner Production 15(11-12), 994-1006. https://doi.org/10.1016/j.jclepro.2006.05.019

Pavlínek, P. Zenka, J. 2011. Upgrading in the automotive industry: firm-level evidence from Central Europe. Journal of Economic Geography, 11(3) 559-586, https://doi.org/10.1093/jeg/lbq023

Radosevic, S. Rozeik, A. 2005. Foreign direct investment and restructuring in the automotive industry in Central and East Europe. Working Paper No. 53. UCL, London. 41

Sánchez, A. M., Pérez, M. P. 2005. Supply chain flexibility and firm performance: A conceptual model and empirical study in the automotive industry, International Journal of Operations \& Production Management, 25(7) 681-700. https://doi.org/10.1108/01443570510605090

Stros, M., Říha, D., Říhová, E., \& Lim, L. L. (2019). Personal sales success factors in a wealthy market environment. Journal of Eastern European and Central Asian Research, 6(1), 24-39. https://doi.org/10.15549/jeecar.v6i1.270

Szegedi, Z., Gábriel, M. and Papp, I. 2017. Green supply chain awareness in the Hungarian automotive industry. Polish Journal of management Studies 16 (1) 259-268. https://doi.org/10.17512/pjms.2017.16.1.22

Sturgeon, T. J.,Van Biesebroeck, J. 2011. Global value chains in the automotive industry: An enhanced role for developing countries? International Journal of Technological Learning, Innovation and Development, 4(13), 181-205, https://doi.org/10.1504/IJTLID.2011.041904

Thun, J.-H., Hoenig, D. 2011. An empirical analysis of supply chain risk management in 
the German automotive industry, International Journal of Production Economics, 131(1) 242-249. https://doi.org/10.1016/j.ijpe.2009.10.010

Turzai-Horányi B. 2019. The Life Cycle of the Hungarian Car Dealerships and the effect of the 2008 Crisis on their development. Thesis of PhD Dissertation, Szent István University, Gödöllő

Van Biesebroeck, J. Sturgeon, T. 2010. Effects of the 2008-09 Crisis on the Automotive Industry in Developing Countries: A Global Value Chain Perspective. 209-244. In: Cattaneo, O. et al. (eds.), Global Value Chains in a Postcrisis World: A Development Perspective, The World Bank, Washington DC.

Wells, P. 2010. The automotive industry in an era of Eco-austerity: creating an industry as if the planet mattered. Cheltenham, UK: Edward Elgar Publishing.

Winter, J. 2010. Upgrading of TNC Subsidiaries: The Case of the Polish Automotive Industry. International Journal of Automotive Technology and Management, 10(2-3) 145160. https://doi.org/10.1504/IJATM.2010.032621

Zhang, X. 2014. Analysis for Scale-Free Network Characteristics of Logistics Distribution Network. Journal of Service Science and Management. 7(3), 189-195. http://dx.doi.org/10.4236/jssm.2014.73015

\section{ABOUT THE AUTHORS}

Anna Dunay, email: dunay.anna@uni-mate.hu

Dr. Csaba Bálint Illés, CSc has been a Full Professor of management since 2005 at Szent István University, Gödöllő, Hungary. He is the director of the Institute of Business Economics, Leadership and Management and director of the Executive MBA programme. He is a core member, supervisor and lecturer at the Doctoral School of Management and Business Administration. His current research interests are management and development of enterprises, corporate competitiveness, food safety management and Corporate Social Responsibility in different sectors. He is a member of the editorial boards of many Hungarian and international scientific journals.

Dr. Beatrix Turzai-Horányi, Ph.D. is a lecturer at the Institute of Business Economics, Leadership and Management of the Faculty of Economics and Social Sciences at Szent István University, Gödöllő, Hungary. She possesses 14-year experience in teaching. She teaches courses of Project Management, SME's Management and Business Planning. In her scientific research, she focuses on the competitiveness and lifecycle of small and medium-sized enterprises.

Dr. Anna Dunay, Ph.D. is a Full Professor and Head of the department at the Institute of Business Economics, Leadership and Management of the Faculty of Economics and Social Sciences at Szent István University, Gödöllő, Hungary and Visiting Professor at the University of Silesia, Katowice, Poland. Her main research fields are management of SMEs, entrepreneurship education, Corporate Social Responsibility in different sectors and company competitiveness. She works on the editorial board of Hungarian and international journals and in committees of international scientific conferences in CEE countries. She is the author of more than 260 scientific publications. 